\title{
Leifsonia soli sp. nov., a yellow-pigmented actinobacterium isolated from teak rhizosphere soil
}

\author{
Correspondence \\ Munusamy Madhaiyan \\ mmadhaiyan@hotmail.com
}

\author{
Munusamy Madhaiyan, ${ }^{1}$ Selvaraj Poonguzhali, ${ }^{1}$ Jung-Sook Lee, ${ }^{2}$ \\ Murugaiyan Senthilkumar, ${ }^{3}$ Keun Chul Lee ${ }^{2}$ and Subbiah Sundaram ${ }^{1}$
}

\author{
${ }^{1}$ Department of Agricultural Microbiology, Tamilnadu Agricultural University, Coimbatore 641003 , \\ Tamilnadu, India \\ ${ }^{2}$ Korean Collection for Type Cultures (KCTC), Biological Resource Center (BRC), Korea Research \\ Institute of Bioscience and Biotechnology (KRIBB), 111 Gwahangno, Yusong-gu, Daejeon \\ 305-806, Republic of Korea \\ ${ }^{3}$ Department of Agricultural Microbiology, Horticultural College and Research Institute, Tamilnadu \\ Agricultural University, Periyakulam 625 604, Tamilnadu, India
}

\begin{abstract}
Two yellow-pigmented, Gram-stain-positive, aerobic, motile, short rod-shaped bacteria were isolated from natural teak tree rhizosphere soil and their taxonomic positions were determined by using a polyphasic approach. Comparative 16S rRNA gene sequence analysis showed that strains TG-S248 ${ }^{\top}$ and TG-S240 formed a distinct phyletic line within the genus Leifsonia. $16 \mathrm{~S}$ rRNA gene sequence analysis of strain TG-S248 ${ }^{\top}$ with sequences from Leifsonia shinshuensis DB $102^{\top}$, L. poae VKM Ac-1401 ${ }^{\top}$, L. naganoensis DB $103^{\top}$, L. aquatica DSM $20146^{\top}$ and L. xyli subsp. cynodontis JCM $9733^{\top}$ revealed pairwise similarities ranging from 98.7 to $99.1 \%$. The major fatty acids were anteiso- $C_{15: 0}$, anteiso- $C_{17: 0}$ and iso- $C_{16: 0}$. The $G+C$ content of the DNA of the type strain was 69.4 mol\%. DNA-DNA hybridization experiments revealed low levels of DNA-DNA relatedness (32\% or less) between strain TG-S248 ${ }^{\top}$ and its closest relatives. Based on differences in phenotypic and genotypic characteristics, strain TG-S248 ${ }^{\top}$ (=LMG $24767^{\top}=\mathrm{JCM} 15679^{\top}$ ) is designated the type strain of a novel species of the genus Leifsonia, for which the name Leifsonia soli sp. nov. is proposed.
\end{abstract}

The genus Leifsonia, which is classified in the class Actinobacteria (Evtushenko et al., 2000), currently harbours 12 species and two subspecies, with Leifsonia aquatica as the type species (http://www.bacterio.cict.fr/l/leifsonia. html). L. aquatica, isolated from distilled water, was originally classified as 'Corynebacterium aquaticum' on the basis of its morphological and physiological characteristics (Leifson, 1962). Subsequently, Clavibacter xyli subsp. cynodontis (Davis et al., 1984), originally isolated from the xylem of bermudagrass (Cynodontis dactylon L. Per.), was reclassified as Leifsonia xyli subsp. cynodontis (Evtushenko et al., 2000). This bacterium colonized the xylem vessels of maize (Zea mays L.) to a high titre when it was artificially inoculated (Lampel et al., 1994). Inoculation with engineered strains of this and other endophytic bacteria into

Abbreviation: ACC, 1-aminocyclopropane-1-carboxylate.

The GenBank/EMBL/DDBJ accession numbers for the 16S rRNA gene sequences of strains TG-S248 ${ }^{\top}$ and TG-S240 are EU912483 and EU912481, respectively.

Carbon source utilization patterns and scanning electron micrographs are available as supplementary material with the online version of this paper. plants could improve the resistance of plants to disease and insects and also diminish the effect of environmental pollutants (Barac et al., 2004; Fahey et al., 1991). Leifsonia xyli subsp. $x y l i$ is the causative agent of ratoon stunting disease, a major cause of economic loss in sugar cane crops (Sutcliffe \& Hutchings, 2007). Members of the genus Leifsonia have also been isolated from roots, soil, Himalayan glaciers, cyanobacterial mats and water samples (Evtushenko et al., 2000; Reddy et al., 2003; Dastager et al., 2008, 2009; Hao et al., 2008). This paper presents the formal taxonomic description of a novel species of the genus Leifsonia isolated from teak rhizosphere soil, the strains of which produce phytohormones and 1-aminocyclopropane-1-carboxylate (ACC) deaminase, which enable them to promote plant growth.

Strains designated TG-S248 ${ }^{\mathrm{T}}$ and TG-S240 were isolated from rhizosphere soils of natural teak (Tectona grandis Linn.) by the dilution-plating technique on R2A medium (Reasoner \& Geldreich, 1985) (Difco) and were maintained as $50 \%$ glycerol stocks at $-80{ }^{\circ} \mathrm{C}$. Their carbon source utilization patterns were studied using Biolog GP2 microplates following the manufacturer's instructions and acid production from various sugars was tested by 
the methods of Smith et al. (1952) and Madhaiyan et al. (2007b). Colony and cell morphology were determined by using phase-contrast microscopy. Sample preparation and other procedures for scanning electron microscope observations were performed as described by Madhaiyan et al. (2007b). The samples were visualized using a Hitachi S-2500C with a Gemini column (Hitachi) equipped with a field emission source. Polar lipids and menaquinones were extracted and analysed according to Minnikin et al. (1984) and Kroppenstedt (1982). Preparation of cell walls and determination of peptidoglycan structure were performed as described by Schleifer \& Kandler (1972), with the modification that TLC on cellulose sheets (Merck) was used instead of paper chromatography. Cell-wall sugars were identified according to the methods described by Maltsev et al. (1992). Cellular fatty acids were extracted from cultures grown in R2A medium at $28{ }^{\circ} \mathrm{C}$ for $4-5$ days, derivatized to methyl esters and analysed with a gas chromatograph (Hewlett Packard 6890) using the Microbial Identification System software package (Microbial ID), according to standard protocols (Sasser, 1990). The minimal inhibitory concentrations of heavy metals and the antibiotic resistance patterns of the strains were determined as described by Madhaiyan et al. (2007a) and Chanprame et al. (1996). A quantitative assay for indole-3-acetic acid and plate assays for detecting the presence of siderophore production, phosphate solubilization, ACC deaminase activity and sulfur oxidation were carried out as previously described (Poonguzhali et al., 2006). A gnotobiotic growth pouch assay was performed to measure root elongation induced by ACC deaminase in tomato and canola, which are ethylene-sensitive plants (Glick et al., 1994; Li et al., 2000; Penrose \& Glick, 2003; Ghosh et al., 2003; Madhaiyan et al., 2006, 2007b).

The cells of strains TG-S248 ${ }^{\mathrm{T}}$ and TG-S240 were aerobic, motile, non-endospore forming, Gram-stain-positive, short rods $(0.4-0.5 \times 0.6-0.9 \mu \mathrm{m})$, occurring singly or in pairs, in yellow, circular and opaque colonies with entire margins on R2A agar. Scanning electron micrographs are shown in Supplementary Fig. S1 (available in IJSEM Online). The major fatty acids of strain TG-S248 ${ }^{\mathrm{T}}$ were anteiso- $\mathrm{C}_{15: 0}(40.1 \%)$, iso- $\mathrm{C}_{16: 0}(14.3 \%)$, anteiso- $\mathrm{C}_{17: 0}$ $(34.7 \%)$, iso- $\mathrm{C}_{15: 0}(7.9 \%)$ and iso- $\mathrm{C}_{17: 0}(2.6 \%)$. The nutritional and physiological characteristics of strains TG$\mathrm{S} 248^{\mathrm{T}}$ and TG-S240 are listed in the species description and the characteristics that differentiate them from their closest relatives are presented in Table 1. Strains TG-S248 ${ }^{\mathrm{T}}$ and TG-S240 differed from their closest relatives in utilization of several carbon sources (Supplementary Table S1). Both strains exhibited ACC deaminase activity, phosphate solubilization and sulfur oxidation when examined by plate assays, but were negative for siderophore production. Strains TG-S248 ${ }^{\mathrm{T}}$ and TG-S240 produced, respectively, 2.1 and $3.2 \mu \mathrm{g}$ indole-3-acetic acid $\mathrm{ml}^{-1}$ and 16.2 and $21.3 \mathrm{nmol} \alpha$-ketobutyrate $\mathrm{min}^{-1}$ (mg protein) ${ }^{-1}$ (as an indication of ACC deaminase activity). In the gnotobiotic growth pouch assay, the root lengths of the Leifsoniatreated tomato and canola seeds were comparatively greater when compared with the uninoculated control (data not shown).

Chromosomal DNA was extracted according to the kit instructions (QIAamp DNA mini kit; Qiagen). The 16S rRNA gene was amplified using the universal primers $27 \mathrm{~F}$ and $1492 \mathrm{R}$ as described by Madhaiyan et al. (2009). The partial gene sequence was determined by the fluorescent dye terminator method using an ABI Prism BigDye Terminator cycle sequencing ready reaction version 3.1 kit and an ABI Prism 310 Genetic Analyzer (Applied Biosystems) according to the manufacturer's instructions. The resultant sequences were compared with sequences from Leifsonia and related genera in GenBank and aligned by using CLUSTAL W (Thompson et al., 1994). Phylogenetic relationships were determined by the neighbour-joining method (Saitou \& Nei, 1987) with the program MEGA version 3.1 (Kumar et al., 2004). Bootstrap confidence values were obtained using 1000 resamplings. DNA-DNA hybridizations were carried out on nitrocellulose membranes according to the method of Seldin \& Dubnau (1985). The DIG-High Prime system and DIG luminescent detection kit (Roche Diagnostics) were used for labelling the probe DNA and visualization. Hybridization was carried out at 60 and $65^{\circ} \mathrm{C}$, and DNA-DNA relatedness was quantified by using a densitometer (Bio-Rad Laboratories). The $\mathrm{G}+\mathrm{C}$ content of the genomic DNA was determined by HPLC as described by Mesbah et al. (1989) using a Supelcosil LC-18 S reversed-phase column (Supelco).

The 16S rRNA gene sequence phylogenetic tree placed strains TG-S248 ${ }^{\mathrm{T}}$ and TG-S240 in the genus Leifsonia, grouping with $L$. shinshuensis $\mathrm{DB} 102^{\mathrm{T}}, L$. poae VKM Ac- $1401^{\mathrm{T}}$, L. naganoensis DB $103^{\mathrm{T}}$, L. aquatica DSM $20146^{\mathrm{T}}$ and L. xyli subsp. cynodontis JCM $9733^{\mathrm{T}}$ (Fig. 1). Pairwise sequence similarities ranged from $98.7-99.1 \%$. Strains TG-S248 ${ }^{\mathrm{T}}$ and TG-S240 showed a high level of DNA-DNA relatedness $(83 \pm 7.9 \%)$ with each other and low levels of relatedness with $L$. shinshuensis JCM $10591^{\mathrm{T}}(21 \pm 1.7 \%)$, L. poae DSM $15202^{\mathrm{T}}(26 \pm 2.2 \%), L$. naganoensis $\mathrm{JCM} 10592^{\mathrm{T}}(31 \pm 2.9 \%)$, L. aquatica DSM $20146^{\mathrm{T}}(29 \pm 2.6 \%)$ and $L$. xyli subsp. cynodontis JCM $9733^{\mathrm{T}}(32 \pm 2.7 \%)$. Based on the DNA-DNA hybridization data and the recommendation of a threshold value of $70 \%$ DNA-DNA relatedness for species definition (Wayne et al., 1987), it is clear that strains TG-S248 ${ }^{\mathrm{T}}$ and TG-S240 do not belong to any of the previously described species of Leifsonia. The DNA G + C content of strain TG-S248 ${ }^{\mathrm{T}}$ was $69.4 \mathrm{~mol} \%$, which falls within the range described for the genus Leifsonia (Evtushenko et al., 2000).

On the basis of the results presented, strains TG-S $248^{\mathrm{T}}$ and TG-S240 are members of a novel species of Leifsonia, for which we propose the name Leifsonia soli sp. nov. 
Table 1. Physiological and biochemical properties of strains TG-S248 ${ }^{\top}$ and TG-S240 that differentiate them from their closest phylogenetic neighbours in the genus Leifsonia

Strains: 1 , Leifsonia soli sp. nov. TG-S248 ${ }^{\mathrm{T}} ; 2$, Leifsonia soli sp. nov. TG-S240; 3, L. shinshuensis JCM 10591 ${ }^{\mathrm{T}} ; 4$, L. poae DSM 15202 ${ }^{\mathrm{T}}$; 5, L. aquatica

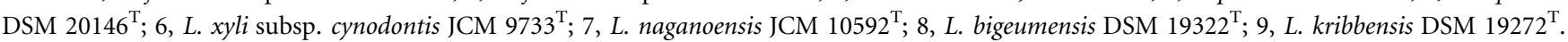
Data in columns 7-9 were obtained from Suzuki et al. (1999), Reddy et al. (2003) and Dastager et al. (2008, 2009). All other data were determined in this study. +, Positive; w, weakly positive; -, negative; ND, no data available.

\begin{tabular}{|c|c|c|c|c|c|c|c|c|c|}
\hline Characteristic & 1 & 2 & 3 & 4 & 5 & 6 & 7 & 8 & 9 \\
\hline Colony colour ${ }^{\star}$ & $\mathrm{Y}$ & $\mathrm{Y}$ & wH & $\mathrm{Y}$ & $\mathrm{Y}$ & $\mathrm{Y}$ & WH & PY & Y \\
\hline Motility & + & + & - & + & + & - & - & + & + \\
\hline Oxidase & $\mathrm{W}$ & - & - & - & + & - & $\mathrm{ND}$ & - & - \\
\hline Catalase & + & + & + & + & + & + & + & - & - \\
\hline Growth temperature $\left({ }^{\circ} \mathrm{C}\right)$ & $10-35$ & $10-35$ & $7-42$ & $4-37$ & $7-37$ & $7-35$ & $7-37$ & $20-37$ & $20-37$ \\
\hline Growth with $5 \% \mathrm{NaCl}$ & - & $\mathrm{w}$ & - & - & + & - & - & - & - \\
\hline Methyl red test & $\mathrm{W}$ & + & + & + & - & - & $\mathrm{ND}$ & $\mathrm{ND}$ & $\mathrm{ND}$ \\
\hline Voges-Proskauer test & - & - & - & - & - & + & ND & $\mathrm{ND}$ & $\mathrm{ND}$ \\
\hline $\mathrm{H}_{2} \mathrm{~S}$ production & - & - & - & - & + & - & ND & - & - \\
\hline \multicolumn{10}{|l|}{ Hydrolysis of: } \\
\hline Starch & + & + & + & - & + & + & + & + & $\mathrm{W}$ \\
\hline Aesculin & + & + & $\mathrm{w}$ & + & - & - & ND & - & - \\
\hline Gelatin & - & - & - & + & - & - & ND & - & - \\
\hline \multicolumn{10}{|l|}{ Acid production from: } \\
\hline L-Arabinose & + & + & - & + & - & - & $\mathrm{ND}$ & - & - \\
\hline D-Fructose & + & + & + & + & + & + & + & - & - \\
\hline D-Galactose & - & - & - & + & + & - & + & - & - \\
\hline D-Glucose & + & + & - & - & + & + & + & - & - \\
\hline Maltose & + & + & - & - & - & - & + & - & - \\
\hline D-Mannose & + & + & - & + & - & + & + & - & - \\
\hline \multicolumn{10}{|c|}{ Utilization as sole carbon source of: } \\
\hline L-Arabinose & $\mathrm{w}$ & $\mathrm{w}$ & - & + & - & - & ND & - & - \\
\hline Cellobiose & + & + & - & + & + & - & + & + & + \\
\hline D-Fructose & $\mathrm{w}$ & $\mathrm{W}$ & + & + & + & + & + & - & - \\
\hline D-Galactose & $\mathrm{w}$ & $\mathrm{w}$ & $\mathrm{w}$ & + & + & - & + & - & - \\
\hline D-Glucose & + & + & - & $\mathrm{w}$ & + & + & + & - & - \\
\hline myo-Inositol & - & - & + & - & + & - & + & + & + \\
\hline D-Mannitol & $\mathrm{W}$ & + & + & + & + & + & + & + & + \\
\hline D-Mannose & + & + & + & + & $\mathrm{w}$ & + & + & - & - \\
\hline Melibiose & - & - & + & + & + & - & $\mathrm{W}$ & + & + \\
\hline Raffinose & - & - & - & + & - & - & $\mathrm{ND}$ & + & + \\
\hline D-Rhamnose & - & - & $\mathrm{w}$ & - & + & - & - & + & + \\
\hline D-Ribose & - & $\mathrm{W}$ & $\mathrm{W}$ & - & - & - & $\mathrm{w}$ & - & - \\
\hline Trehalose & + & + & + & - & + & - & $\mathrm{w}$ & + & + \\
\hline \multicolumn{10}{|l|}{ Fatty acids ( $\%$ of total content) } \\
\hline $\mathrm{C}_{16: 0}$ & - & 3.0 & 0.8 & 2.8 & 0.6 & 1.8 & 3.4 & 1.5 & - \\
\hline iso- $\mathrm{C}_{14: 0}$ & 0.4 & 0.3 & 0.4 & 0.3 & 0.1 & 0.6 & 0.6 & 1.9 & 7.8 \\
\hline iso- $\mathrm{C}_{15: 0}$ & 7.9 & 5.6 & 1.5 & 1.2 & 1.1 & 0.8 & 1.4 & 2.4 & 5.3 \\
\hline anteiso- $\mathrm{C}_{15: 0}$ & 40.1 & 35.7 & 45.2 & 35.2 & 28.3 & 33.5 & 41.5 & 36.0 & 19.7 \\
\hline iso- $\mathrm{C}_{16: 0}$ & 14.3 & 15.5 & 17.2 & 14.9 & 15.2 & 11.5 & 17.5 & 38.9 & 43.4 \\
\hline iso- $\mathrm{C}_{17: 0}$ & 2.6 & 2.5 & 2.4 & 2.1 & 1.5 & 0.9 & 1.8 & 1.1 & 2.1 \\
\hline anteiso- $\mathrm{C}_{17: 0}$ & 34.7 & 37.4 & 32.4 & 43.4 & 53.1 & 50.6 & 33.6 & 18.2 & 6.8 \\
\hline anteiso- $\mathrm{C}_{17: 1} \omega 9 c$ & - & - & - & - & - & - & - & - & 8.7 \\
\hline DNA G $+\mathrm{C}$ content $(\mathrm{mol} \%)$ & 69.4 & 69.5 & 70.7 & 69.5 & 70.3 & 69.4 & 70.5 & 69 & 73.4 \\
\hline Major menaquinone(s) & 11 & 11 & 11,12 & 11 & 11,10 & 11,12 & 11,10 & 11 & 11,12 \\
\hline
\end{tabular}

${ }^{*} \mathrm{PY}$, Pale yellow; wH, white; $\mathrm{Y}$, yellow. 


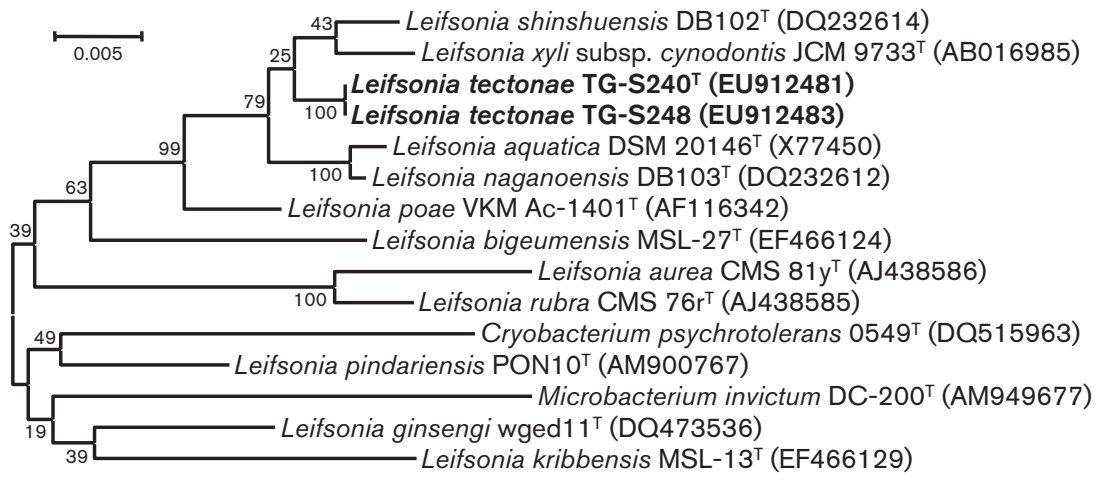

Fig. 1. Neighbour-joining phylogenetic tree based on 16S rRNA gene sequence comparisons showing the positions of strains TG$\mathrm{S}_{248}{ }^{\top}$ and TG-S240 in the genus Leifsonia. Percentages at branch nodes indicate levels of bootstrap support based on 1000 resampled datasets. Bar, 0.005 substitutions per nucleotide position.

\section{Description of Leifsonia soli sp. nov.}

Leifsonia soli (so'li. L. gen. n. soli of soil, referring to the isolation of the first strains from teak tree rhizosphere soil).

Colonies are circular, convex, smooth, yellow and 1.0 $2.8 \mathrm{~mm}$ in diameter on R2A medium after $96 \mathrm{~h}$ at $28^{\circ} \mathrm{C}$. Cells are aerobic, Gram-stain-positive, motile, short rods, $0.4-0.5 \mu \mathrm{m}$ wide by $0.6-0.9 \mu \mathrm{m}$ long, occurring singly or in pairs. Tolerates up to $2.0 \% \mathrm{NaCl}$. Grows at $10-35{ }^{\circ} \mathrm{C}$, with optimum growth at $30{ }^{\circ} \mathrm{C}$, and at $\mathrm{pH}$ 5.0-9.0, with optimum growth at $\mathrm{pH} 6.8$. Negative for degradation of cellulose, gelatin and pectin. Positive for decomposition of casein, tributyrin, starch and aesculin. Urease, indole production, $\mathrm{H}_{2} \mathrm{~S}$ production and reduction of nitrate are negative. Positive for the methyl red test and negative for the Voges-Proskauer test. Produces acid from L-arabinose, D-fructose, D-glucose, maltose and D-mannose but not from D-galactose. The yellow pigment is water-insoluble and has absorption maxima at 210,253, 450 and $480 \mathrm{~nm}$ in methanol. Grows on R2A agar, TSA and NA, but not on MacConkey agar. Tolerates up to $0.5 \mathrm{mM} \mathrm{NiCl} 2$ and $<0.5 \mathrm{mM} \mathrm{CdCl}{ }_{2}$ in plate assays: no growth observed at higher concentrations. With the Biolog GP2 MicroPlate system, utilizes dextrin, Tweens 40 and 80, L-arabinose, cellobiose, D-fructose, D-galactose, D-gluconic acid, $\alpha$-Dglucose, maltose, maltotriose, D-mannitol, D-mannose, melezitose, palatinose, salicin, D-sorbitol, sucrose, trehalose, turanose, D-xylose, pyruvic acid methyl ester, succinic acid monomethyl ester, glycerol and adenosine, but not $\alpha$ or $\beta$-cyclodextrin, inulin, mannan, $N$-acetyl-D-galactosamine, $N$-acetyl- $\beta$-D-mannosamine, D-arabitol, D-galacturonic acid, myo-inositol, $\alpha$-lactose, lactulose, melibiose, methyl $\alpha$-D-galactoside, methyl $\beta$-D-galactoside, 3-methyl D-glucose, methyl $\beta$-D-glucoside, methyl $\alpha$-D-mannoside, raffinose, L-rhamnose, sedoheptulosan, stachyose, D-tagatose, xylitol, $\alpha$-, $\beta$ - or $\gamma$-hydroxybutyric acid, $p$-hydroxyphenylacetic acid, $\alpha$-ketobutyric acid, $\alpha$-ketovaleric acid, lactamide, D-lactic acid methyl ester, L-lactic acid, D- or Lmalic acid, propionic acid, succinamic acid, succinic acid, $\mathrm{N}$-acetyl-L-glutamic acid, D- or L-alanine, L-alanyl glycine, L-asparagine, L-glutamic acid, glycyl L-glutamic acid, L-pyroglutamic acid, L-serine, putrescine, 2,3-butanediol, $2^{\prime}$-deoxyadenosine, inosine, uridine, adenosine $5^{\prime}$-monophosphate, thymidine $5^{\prime}$-monophosphate, uridine $5^{\prime}$ - monophosphate, D-fructose 6-phosphate, $\alpha$-D-glucose 1phosphate, D-glucose 6-phosphate or DL- $\alpha$-glycerol phosphate. The type strain is highly resistant (up to $500 \mu \mathrm{g}$ $\mathrm{ml}^{-1}$ ) to ampicillin, carbenicillin, nalidixic acid and bacitracin but sensitive to (lowest concentration; $\mu \mathrm{g}$ $\mathrm{ml}^{-1}$ ) gentamicin (25), kanamycin (300), cefotaxime (50), chloramphenicol (300), spectinomycin (500), doxycycline (100), erythromycin (25), penicillin G (100), polymyxin B (500), rifampicin (25), novobiocin (100), tetracycline (500), cephalosporin (25), vancomycin (25) and trimethoprim (25). The cell-wall peptidoglycan contains alanine, 2,4-diaminobutyric acid, glutamic acid and glycine (molar ratio $1: 2: 1: 1$ ). The cell-wall sugars are galactose, glucose, mannose and rhamnose. Phospholipids detected are diphosphatidylglycerol, phosphatidylglycerol and several unidentified lipids. Major fatty acids are anteiso- $\mathrm{C}_{15: 0}$, anteiso- $\mathrm{C}_{17: 0}$ and iso- $\mathrm{C}_{16: 0}$. The major menaquinone is MK-11. The $\mathrm{G}+\mathrm{C}$ content of the DNA of the type strain is $69.4 \mathrm{~mol} \%$.

The type strain, TG-S248 ${ }^{\mathrm{T}}\left(=\mathrm{LMG} 24767^{\mathrm{T}}=\mathrm{JCM} 15679^{\mathrm{T}}\right)$, was isolated from rhizosphere soil of natural teak (Tectona grandis Linn.), the sample being collected from Field No. 37, Tamilnadu Agricultural University (TNAU), Coimbatore, Tamilnadu, India.

\section{Acknowledgements}

We wish to thank Yoshimasa Kosako, Japan Collection of Microorganisms, RIKEN, Wako, Japan, and ir. Claudine Vereecke, BCCM/LMG Bacteria Collection, Belgium, for their valuable advice. We also thank Dr Jean P. Euzéby for his valuable advice on nomenclature. M. M. was supported through funds provided by the Indian Council of Agricultural Research (ICAR), New Delhi, India.

\section{References}

Barac, T., Taghavi, S., Borremans, B., Provoost, A., Oeyen, L., Colpaert, J. V., Vangronsveld, J. \& van der Lelie, D. (2004). Engineered endophytic bacteria improve phytoremediation of water solution, volatile, organic pollution. Nat Biotechnol 22, 583-588.

Chanprame, S., Todd, J. J. \& Widholm, J. M. (1996). Prevention of pink-pigmented methylotrophic bacteria (Methylobacterium mesophilicum) contamination of plant tissue cultures. Plant Cell Rep 16, 222225. 
Dastager, S. G., Lee, J.-C., Ju, Y.-J., Park, D.-J. \& Kim, C.-J. (2008). Leifsonia bigeumensis sp. nov., isolated from soil on Bigeum Island, Korea. Int J Syst Evol Microbiol 58, 1935-1938.

Dastager, S. G., Lee, J.-C., Ju, Y.-J., Park, D.-J. \& Kim, C.-J. (2009). Leifsonia kribbensis sp. nov., isolated from soil. Int J Syst Evol Microbiol 59, 18-21.

Davis, M. J., Gillaspie, A. G., Jr, Vidaver, A. K. \& Harris, R. W. (1984). Clavibacter: a new genus containing some phytopathogenic coryneform bacteria, including Clavibacter xyli subsp. xyli sp. nov., subsp. nov. and Clavibacter xyli subsp. cynodontis subsp. nov., pathogens that cause ratoon stunting disease of sugarcane and bermudagrass stunting disease. Int J Syst Bacteriol 34, 107-117.

Evtushenko, L. I., Dorofeeva, L. V., Subbotin, S. A., Cole, J. R. \& Tiedje, J. M. (2000). Leifsonia poae gen. nov., sp. nov., isolated from nematode galls on Poa annua, and reclassification of 'Corynebacterium aquaticum' Leifson 1962 as Leifsonia aquatica (ex Leifson 1962) gen. nov., nom. rev., comb. nov. and Clavibacter xyli Davis et al., 1984 with two subspecies as Leifsonia xyli (Davis et al., 1984) gen. nov., comb. nov. Int J Syst Evol Microbiol 50, 371-380.

Fahey, J. W., Dimock, M. B., Tomasino, S. F., Taylor, J. M. \& Carlson, P. S. (1991). Genetically engineered endophytes as biocontrol agents: a case study in industry. In Microbial Ecology of Leaves, pp. 401-411. Edited by J. H. Andrews \& S. S. Hirano. New York: Springer.

Ghosh, S., Penterman, J. N., Little, R. D., Chavez, R. \& Glick, B. R. (2003). Three newly isolated plant growth-promoting bacilli facilitate the seedling growth of canola, Brassica campestris. Plant Physiol Biochem 41, 277-281.

Glick, B. R., Jacobson, C. B., Schwarze, M. M. K. \& Pasternak, J. J. (1994). 1-Aminocyclopropane-1-carboxylic acid deaminase mutants of the plant growth promoting rhizobacterium Pseudomonas putida GR12-2 do not stimulate canola root elongation. Can J Microbiol 40, 911-915.

Hao, D. C., Ge, G. B. \& Yang, L. (2008). Bacterial diversity of Taxus rhizosphere: culture-independent and culture-dependent approaches. FEMS Microbiol Lett 284, 204-212.

Kroppenstedt, R. M. (1982). Separation of bacterial menaquinones by HPLC using reverse phase (RP18) and a silver loaded ion exchanger as stationary phases. J Liq Chromatogr 5, 2359-2367.

Kumar, S., Tamura, K. \& Nei, M. (2004). MEGA3: integrated software for molecular evolutionary genetics analysis and sequence alignment. Brief Bioinform 5, 150-163.

Lampel, J. S., Canter, G. L., Dimoch, M. B., Kelly, J. L., Anderson, J. J., Uratani, B. B., Foulke, J. S., Jr \& Turner, J. T. (1994). Integrative cloning, expression, and stability of the crylA(c) gene from Bacillus thuringiensis subsp. kurstaki in a recombinant strain of Clavibacter xyli subsp. cynodontis. Appl Environ Microbiol 60, 501-508.

Leifson, E. (1962). The bacterial flora of distilled and stored water. III. New species of the genera Corynebacterium, Flavobacterium, Spirillum, and Pseudomonas. Int Bull Bacteriol Nomencl Taxon 12, 161-170.

Li, J., Ovakim, D. H., Charles, T. C. \& Glick, B. R. (2000). An ACC deaminase minus mutant of Enterobacter cloacae UW4 no longer promotes root elongation. Curr Microbiol 41, 101-105.

Madhaiyan, M., Poonguzhali, S., Ryu, J.-H. \& Sa, T.-M. (2006). Regulation of ethylene levels in canola (Brassica campestris) by 1aminocyclopropane-1-carboxylate deaminase-containing Methylobacterium fujisawaense. Planta 224, 268-278.

Madhaiyan, M., Poonguzhali, S. \& Sa, T. M. (2007a). Metal tolerating methylotrophic bacteria reduces nickel and cadmium toxicity and promotes plant growth of tomato (Lycopersicon esculentum L.). Chemosphere 69, 220-228.

Madhaiyan, M., Kim, B.-Y., Poonguzhali, S., Kwon, S.-W., Song, M.-H., Ryu, J.-H., Go, S.-J., Koo, B.-S. \& Sa, T.-M. (2007b).
Methylobacterium oryzae sp. nov., an aerobic, pink-pigmented, facultatively methylotrophic, 1-aminocyclopropane-1-carboxylate deaminase-producing bacterium isolated from rice. Int J Syst Evol Microbiol 57, 326-331.

Madhaiyan, M., Poonguzhali, S., Kwon, S. W. \& Sa, T. M. (2009). Methylobacterium phyllosphaerae sp. nov., a pink-pigmented facultatively methylotrophic bacterium from rice. Int J Syst Evol Microbiol 59, 22-27.

Maltsev, I. I., Kalinovskii, A. I., Zgurskaya, H. I. \& Evtushenko, L. I. (1992). Tyvelose in Agromyces cell walls. Syst Appl Microbiol 15, 187190.

Mesbah, M., Premachandran, U. \& Whitman, W. B. (1989). Precise measurement of the $\mathrm{G}+\mathrm{C}$ content of deoxyribonucleic acid by highperformance liquid chromatography. Int J Syst Bacteriol 39, 159-167.

Minnikin, D. E., O’Donnell, A. G., Goodfellow, M., Alderson, G., Athalye, M., Schaal, A. \& Parlett, J. H. (1984). An integrated procedure for the extraction of bacterial isoprenoid quinones and polar lipids. J Microbiol Methods 2, 233-241.

Penrose, D. M. \& Glick, B. R. (2003). Methods for isolating and characterizing ACC deaminase-containing plant growth-promoting rhizobacteria. Physiol Plant 118, 10-15.

Poonguzhali, S., Madhaiyan, M. \& Sa, T. (2006). Cultivationdependent characterization of rhizobacterial communities from field grown Chinese cabbage Brassica campestris ssp. pekinensis and screening of traits for potential plant growth promotion. Plant Soil 286, 167-180.

Reasoner, D. J. \& Geldreich, E. E. (1985). A new medium for the enumeration and subculture of bacteria from potable water. Appl Environ Microbiol 49, 1-7.

Reddy, G. S. N., Prakash, J. S. S., Srinivas, R., Matsumoto, G. I. \& Shivaji, S. (2003). Leifsonia rubra sp. nov. and Leifsonia aurea sp. nov., psychrophiles from a pond in Antarctica. Int $J$ Syst Evol Microbiol 53, 977-984.

Saitou, N. \& Nei, M. (1987). The neighbor-joining method: a new method for reconstructing phylogenetic trees. Mol Biol Evol 4, 406425.

Sasser, M. (1990). Identification of bacteria through fatty acid analysis. In Methods in Phytobacteriology, pp. 199-204. Edited by Z. Klement, K. Rudolph \& D. C. Sands. Budapest: Akademiai Kiado.

Schleifer, K. H. \& Kandler, O. (1972). Peptidoglycan types of bacterial cell walls and their taxonomic implications. Bacteriol Rev 36, 407-477.

Seldin, L. \& Dubnau, D. (1985). Deoxyribonucleic acid homology among Bacillus polymyxa, Bacillus macerans, Bacillus azotofixans, and other nitrogen-fixing Bacillus strains. Int J Syst Bacteriol 35, 151154.

Smith, N. R., Gordon, R. E. \& Clark, F. E. (1952). Aerobic Spore Forming Bacteria. Agricultural Monograph no. 16. Washington, DC: US Department of Agriculture.

Sutcliffe, I. C. \& Hutchings, M. I. (2007). Putative lipoproteins identified by bioinformatic genome analysis of Leifsonia xyli ssp. xyli, the causative agent of sugarcane ratoon stunting disease. Mol Plant Biol 8, 121-128.

Suzuki, K., Suzuki, M., Sasaki, J., Park, Y. H. \& Komagata, K. K. (1999). Leifsonia gen. nov., a genus for 2,4-diaminobutyric acidcontaining actinomycetes to accommodate 'Corynebacterium aquaticum' Leifson 1962 and Clavibacter xyli subsp. cynodontis Davis et al. 1984. J Gen Appl Microbiol 45, 253-262.

Thompson, J. D., Higgins, D. G. \& Gibson, T. J. (1994). CLUSTAL W: improving the sensitivity of progressive multiple sequence alignment through sequence weighting, position-specific gap penalties and weight matrix choice. Nucleic Acids Res 22, 4673-4680. 
Wayne, L. G., Brenner, D. J., Colwell, R. R., Grimont, P. A. D., Kandler, O., Krichevsky, M. I., Moore, L. H., Moore, W. E. C., Murray, R. G. E. \& other authors (1987). International Committee on Systematic
Bacteriology. Report of the ad hoc committee on reconciliation of approaches to bacterial systematics. Int J Syst Bacteriol 37, 463464. 